\title{
KRONIEK
}

\section{DIE STEM VAN POTCHEFSTROOM}

Op 'n onlangse huldiging van Totius is die uitdrukking ,,die stem van Potchefstroom" in 'n baie gunstige sin toegepas op die groot waarde wat Totius gehad het in die volkslewe op 'n baie breë front. Dis nie die bedoeling hier om in te gaan op die betekenis van Totius op verskillende vlakke nie. Dit word elders, ook in Koers, vollediger gedoen. Iis egter nic te betwyfel nie dat Totius as primus inter pares bygedra het om Potchefstroom 'n welbeluisterde stem in die verlede te maak. Die stem van Totius het met sy „tintinkietaal" wel orals ingedring en 'n onuitwisbare indruk nagclaat. Niemand het die ,klein mannetjie" geken of ontmoet nie, of hy kan jou met decrnis en genoeë daarvan vertel: van sy koddige humor waarmee hy op eienaardige manier declgehad het aan die studentepret, tot die beskrywing van Totius as innemende maar swygsame gas wat 'n hele aand besoek kon aflê sonder om haas een woord te sê. Onder alles was hy bemind en gesog, en een indruk wat 'n mens bybly, is dat hy ervaar was as iemand wat diep geleef, en profeties ver gekyk het.

Die uitdrukking ,,die stem van Potchefstroom”, soos in die huldiging op Totius toegepas, is egter meermale agterna al verklaar as synde verlede tyd. Die stem word nie meer gehoor, of beter: aangehoor, soos vrocër nie. Daarmec word baie gesê: van Totius én van die huidige situasie; van Totius, dat hy 'n unieke, onherhaalbare man was in sy unieke, onherhaalbare omstandighede. Dat hy so graag gehoor was, het sekerlik te make met dic man én met die omstandighede van sy tyd. In die kwart ceu ongevecr na sy dood het daar baic verander. Te midde van politieke, ckonomicse en ander veranderinge het daar ook veranderinge gekom in lewensuitkyk en lewenshouding. Daarom sal die huidige aanhoor van die stem van Potchefstroom ook te make hê met die man of mense wat praat en die standpunte wat gestel word, te midde van die huidige omstandighede. 


\section{In die digkuns}

Onregverdig soos dit is, word hier twee gediggies van Totius geplaas téénoor die jongste digterlike stem van Potchefstroom, dié van Jan Swanepoel. Swanepoel is ' $n$ jong dosent in Latyn, en sy ecrste dibundel, My Rome brand so mooi, het in 1976 by Tafelberg verskyn. Pas uit die dop dus, maar tog besonne, Godgerig en eietyds, soos hy in 'n resensie beskryf is. Onregverdig is die vergelyking, omdat die verse van Totius wat hier afgedruk word, uit 'n ryper lewenservaring gebore is. Tog word hier die ander aanpak, dic sien van ander perspektiewe, die aanvoel en deurlewing van ander en anderse beklemminge duidelik geillustreer.

Albei digters het, aangegryp deur die oerwêreldse motief van die ark, sy eie vergestalting daarvan gegee, Totius in sy gedig ,Weer in die ark" uit sy bundel Skemering:

Stormwaters van die Wêreldvloed het eindelik skuimend uitgewoed.

'n Duif het Noag uit laat vlieg, dié 't oor die golwe heengevlieg.

Maar bo dié ongestuime vloed, was daar geen rusplek vir sy voet.

Uit koue wêreld, wind en weer, het dit na Noag teruggekeer.

Hy 't met sy hand die swerweling, weer in die ark teruggebring.

Swanepoel gebruik dieselfde motief in sy gedig „Uit die ark" uit dis vierde deel van sy bundel: 


\author{
toe ek uit jou oë loskom \\ was ek bang \\ wou ck soos die duif \\ terugvlieg met 'n tak \\ maar nou \\ met die rustig word van my wêreld \\ maak ek 'n eie nes.
}

Nog meer aangrypend is die volgende vergelyking waar albei dig. ters uitdrukking gee aan hulle crvaring van die onweerstaanbare, ongrypbare handele van God met dic mens: Totius in sy oorbekende gedig ,I)ie Godsbesluit", waarin hy op tipiese manier tcruggryp na 'n natuurvergelyking:

Voor die onheilswoning en

tussen die skaars beblaarde

soetdorings staan, in droë aarde

maar lowergroen en blink van blad,

die wag-'n-bietjic langs die pad.

Wanneer ek nader kom dan sien

ck dorings krom en reg;

'k sien takke inmekaar gedraai

en deurmekaar gevleg.

lin wil ek in die blare gryp

of aan die takke breek,

dan tas ek in 'n doringnes

wat vreeslik haak en steck.

Bo al u donker bome, o Ileer, groci my 'n enk'le reusboom uit dit is dic wag-'n-bictjie-bos

van $\mathrm{U}$ besluit.

Van ver so skoon, so groen, so blink...

maar hoc verward

wanneer ek dicper kyk en dink

as wat 'n sondaar pas. 
En steek ek dan my hande uit

$\mathrm{Na}$ U besluit,

dan gryp ek in die dorings vas.

Swanepoel beskryf hierdie ervaring in die gedig ,Ets" uit die eerst afdeling van sy bundel, met tipies eietydse woorde soos "geweld" en ,geraamte".

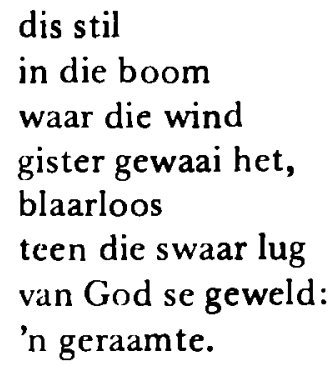

Genoeg. Dis ' $n$ ander man, dis 'n ander tyd, dis ' $n$ ander digtertyd. Dis 'n ander stem.

Die stem en die oor

Lê die aanhoor van die stem by die man wat praat, sy karakter, sy integriteit? Lê dit by die hoorders, hulle behoeftes, hulle lewensuitkyk? Of lê dit dalk by die wyse waarop die karaktervolle man met sy woorde inspeel op die behoeftes van die hoorders?

Miskien lê dit by nie een van die drie nie, maar oor elkeen van die drie kan wel iets gesê word.

Oor die eerste dit: self het ek oor Totius nog nooit een slegte woord gehoor nie, maar ek kan van niémand wat vandag uit Potchefstroom praat, dieselfde sê nie. Dit moet blykbaar gekonstateer word as 'n kenmerk van ons tyd, nie net dat iemand se swakhede buite alle verhoudinge opgeblaas word nie, maar dat daar selfs naarstiglik gesoek word na swakhede of vergrype om op te blaas. En dit wórd gevind, reg of verkeerd. Dit geld ook sekerlik 
nie net van die pers, soos sommige meen nie. Die Heidelberger se verklaring van die negende gebod dat dit elke gelowige se plig is om die eer en goeie naam van sy naaste te beskerm, het, in die hele gemeenskap waarin ons leef, nie meer veel waarde nie. Dis baie makliker om die beeld van iemand af te breek as om dit selfs te laat soos wat God hom begenadig het. In die politieke lewe was dit lankal verstaanbaar, maar nie verskoonbaar nie, op te merk. In die laaste kwart eeu het dit egter hoe langer hoe meer gesneeubal op elkeen wat dit gewaag het ,om sy nek uit te steek".

Oor die tweede vraag kan met stelligheid gesê word dat Totius die mense van sy tyd in hulle behoeftes aangespreek het - van die tyd van heropbou na die Engelse Oorlog af tot na die tweede Wêreldoorlog - as prediker, Bybelvertaler en Psalmberymer, teoloog en ,volksman". En die mense het dit aanvaar omdat hulle daaraan bchoefte gehad het - almal? Seker nie almal ewe veel ten opsigte van alle fasette nie, maar tog wat ons sou kon noem die kern of die hart daarvan. Het daar dan in die laaste kwart eeu 'n verandering ingetree in hierdie kern? Een ondubbelsinnige antwoord sou baie pretensieus wees. Betreffende sekere dinge het daar beslis ' $\mathrm{n}$ verandering ingetree. Wat ander dinge betref, $k$ an verandering met moeite aangetoon, of miskien slegs aangevoel word. Verandering op sigself is ook nie die belangrikste nie. Selfs wat getipeer word as progressie of stagnasie gee nie die antwoord nie, omdat dergelike tiperings en etiketterings altyd gewortel is in 'n subjek tiewe uitgangspunt. Van Totius, om maar by hom te bly, sou ons wel kan lecr dat enige beoordeling moet uitgaan van God se openbaring in die Skrif. Hoewel die Skrifberoep ' $n$ aparte hoofstuk is, kan in hierdie verband die vraag gestel word of die hoorders van die ,stem" nog graag luister na die sprake van die Woord in ons tyd. Ja, natuurlik moet dit ook op die ,stem" toegepas word. Sou dit egter blyk dat die hoorder nie meer behoefte het aan die toepassing van die Skrif nie, terwyl die „stem" hom daarop beroep, is die kommunikasiestoring eenvoudig begryplik. Dan word dit 'n stem roepende in die woestyn, en uit die konteks van Jesaja 40 en Mattheus 3 is dit 'n heel ernstige saak. 
Wanneer oor en stem hulle albei op die Woord beroep, en tog nie bymekaar uitkom in eensgesindheid nie, dan word dit dringend nodig dat die ,ledemate van dieselfde liggaam" (stem en oor) bymekaar moet kom om hulle verskille met mekaar onder oë te sien. Rondom hierdie vraagstuk is byvoorbeeld onlangs 'n kostelike diskussie in Die Kerkblad afgesluit. Hopelik sal dit later weer met groter indringendheid hervat word.

By die derde vraag - oor die wyse waarop ingespeel word op die behoefte van die hoorders - kom 'n baie mcer subticle aspek na vore. Dis goed om te sê: dons in soos Simson en slaan dic Filistyne met 'n eselskakebeen kort en klein. Dit word egter moeiliker as Simson die Israeliete begin slaan. 'n Mens kan jou stem laat hoor op 'n wyse waarmec jy opsetlik daarop uit is om reaksic te wek. Maar jy kan mense maklik van jou afstoot deur krasse oordele en wanneer jy alleen staan, jousclf troos met die voorbeeld van die Ou Testamentiese profete wat ook nie een die populêre leier van 'n juigende skare was nie. Oud-koningin Wilhelmina van Nederland het die onderskeid tussen alleen en eensaam skerp raakgesien toe sy haar lewe getipeer het: „eenzaam maar niet alleen". Sy het weliswaar iets anders daarmee bedoel; maar dis waar dat jy met 'n eensame mens meegevoel het, maar'n alleenmens soek daarna. Die argument beweeg hier op die terrein van die taktvolheid wat in die Koninkryk van God seker 'n opvoedkundige waarde het. Tog mag die taktvolheid ook weer nooit, nooit die kombers van liefde word waarmee die waarheid versmoor word nie. Erens staan dat Vinet sou gesê het (vertaal): „Om welsprekend te wees, is om waaragtig te wees, jou aan die waarheid aan te sluit, jou daarmee te vereenselwig, hartstogtelik daarmee ingenome te wees". Takt en waarheid hoef ook nie teenoor mekaar te staan nie. Veel meer word met taktvolheid hier bedoel: nie uit die hoogte spreek nie, maar solidariteit met die hoorders betoon; dieselfde dus wat iemand anders van die prediking gesê het: „Die kuns om te preek bestaan vir 'n nie-geringe deel daarin om solidêr te wees met hulle wat verleë is met en teenoor en in die geloof". En Totius, in 'n preek oor 2 Thes. 2: „Streng moet ons waarsku, maar met teerheid. Lees maar die for- 
mulier oor die afsnyding. Die bestrawwer is daar net so verbrysel as die een wat bestraf word. Hier is geen 'ag'- en 'wee'-geroep uit die hoogte nic..."

Die hele saak van die stem en die oor is waarskynlik baie ingewikkelder as die antwoord op een van hierdie drie vrae, of selfs die antwoord op al drie saam. Die dikte en welluidendheid van die stem en die aanhoor of nie-aanhoor daarvan het met 'n baie komplekse situasie te make. Alles het deesdae met alles te make, en is dit nie dalk omdat alles so ingewikkeld en inmekaar gewik$\mathrm{kel}$ is dat ons as gevolg van die bome die bos nie meer raaksien nie? En les bes is die hele argument gebou op die veronderstelling dat die stem van Potchefstroom verlede tyd is, sonder om uit ie maak of dit waar is.

\section{Het Potchefstroom nog 'n stem?}

My dunk is dat hieroor geen die minste twyfel is nie: nie meer ' $n$ Totius-stem nie. So 'n figuur word maar eenmaal per eeu aan 'n volk geskenk, laat staan nog 'n gemeenskappie. Maar 'n stem is hier nog wel. Daarmee word geen afbreuk gedoen aan of pretensie gevoer teenoor die stem van enige ander plek of gemeenskap of wat ook al nie. Maar'n duidelike en welluidende stem is hier nog.

So glo ook die Senaat van die Universiteit as hy dit onder meer so formulecr in sy openbaar bekendgemaakte besluit: „Die Senaat glo onwrikbaar dat hierdie inrigting wat bely dat dit die weten. skap "In U Lig" wil beoefen, in hierdie tydsgewrig 'n onmiskenbare plek en 'n God-gegewe taak in ons Vaderland en in die wêreld het".

So 'n besluit het 'n pretensie. 'n Senaat wat so 'n besluit kan neem, moct nie net goed weet wat hy doen nie, maar hy moet ook glo. En dit is seker die belangrikste. Die pretensie geld dan ook nie net die volksdiens, of die wetenskap nie, maar alle fasette van wat vandag van universiteit-wees vereis word - en dit 
"In U Lig". Geen universiteit kan beoordeel word volgens die „stem" van die onwettige optrede van 'n klompie rebelse studente, of volgens die uitspraak van een van sy dosente op 'n politieke verhoog in Durban of Addis Abeba nie. 'n Universiteit is wat hy is kragtens sy universitêre bedrywighede op alle universitêre vlakke. En wat dit betref, het Potchefstroom nog 'n stem. 'n Onderskeidende en gebalanseerde aanhoor van hierdie stem, sal ook reg daaraan laat geskied.

Wat hier op Potchefstroom gesê en gedoen word, is ook duidelik ingestel op die krisis van die tyd waarin ons vandag staan. Oor die krisis-aspek van ons tyd is daar seker min twyfel. En dit kan op menige manier aangetoon word hoe daar op Potchefstroom 'n ingesteldheid is om die krisis tegemoet te gaan. Daarmee is Potchefstroom dan ook wecr op die koers van Totius, wat hierdie merkwaardige woorde oor die Calvinisme uitgespreek het saam met 'n dankwoord teenoor twee besoekers uit die buiteland: "Die Calvinisme stort sy sterkte allermees uit in dae van krisis." En aan die slot: „Al tuimel dan ook alles inmekaar, al verander die aarde van plek, ons sal nie vrees nie. Inteendeel, ons steek die hoof omhoog, want ons verlossing is naby. Ons begroet die krisis!"

\section{E.J.S.}

